\title{
Sekundární infarkt myokardu při kontuzi RIA u pacienta po resuscitaci s pomocí systému LUCAS
}

\author{
Vladimír Tuka', Stanislav Šimek², Miroslav Kůdela ${ }^{3}$ \\ 'III. interní klinika, 1. lékařská fakulta Univerzity Karlovy a Všeobecná fakultní nemocnice, Praha \\ 2II. interní klinika, 1. lékařská fakulta Univerzity Karlovy a Všeobecná fakultní nemocnice, Praha \\ ${ }^{3}$ Ústav soudního lékařství a toxikologie, 1. lékařská fakulta Univerzity Karlovy, Praha, Česká republika
}

Adresa: MUDr. Vladimír Tuka, Ph.D., III. interní klinika, 1. LF UK a VFN, U Nemocnice 2, 12808 Praha 2, e-mail: vladimir.tuka@vfn.cz

Přístroje na zajištění mechanické nepřímé srdeční masáže umožnily kontinuální kardiopulmonální resuscitaci $\mathrm{i}$ během transportu pacienta $\mathrm{z}$ terénu do nemocnice nebo dlouhodobou resuscitaci pacienta např. s těžkým podchlazením. ${ }^{1}$ Četnost a charakter komplikací jsou u mechanické a manuální srdeční masáži srovnatelné. ${ }^{2}$ Mezi komplikace patří kontuze a hemoragie hrudníku, srdce a plic. ${ }^{3} \mathrm{~V}$ naší kasuistice prezentujeme „traumatickou“ okluzi epikardiální tepny, která mimikovala akutní infarkt myokardu s elevacemi úseku ST u pacienta po protrahované (1 h $40 \mathrm{~min}$ ) kardiopulmonální resuscitaci.

Pacient ve věku 65 let byl přivezen do naší nemocnice po kardiopulmonální resuscitaci. Doma byl pacient nejdříve 10 minut resuscitován manželkou, po př́jezdu RZP byla na EKG přítomna fibrilace komor a provedena defibrilace, po níž byla přítomna elektromechanická disociace a pokračováno v resuscitaci. Pacienta se nepodařilo stabilizovat $\mathrm{v}$ terénu během 50 minut resuscitace, a proto byla kvůli transportu zahájena kontinuální srdeční masáž pomocí systému LUCAS. Jako primární prř́činu zástavy lékař prvního kontaktu stanovil akutní infarkt myokardu, přestože nebyla provedena 12 svodová EKG, a proto byl pacient transportován přímo na katetrizační sál naší nemocnice.

Po př́jezdu do nemocnice, 1 hodinu 40 minut od srdeční zástavy (50 minut manuální a 50 minut kontinuální mechanická srdeční masáž), byla po zastavení systému LUCAS přítomna spontánní srdeční aktivita, s akcí 50-60/min s hmatnými pulsacemi na velkých tepnách při katecholaminové podpoře (noradrenalin od RZP), mióza, saturace $90 \%$ při řízené ventilaci $100 \%$ kyslíkem. Na př́ijmovém 12svodovém EKG byla přítomna blokáda pravého Tawarova raménka a elevace úseku ST nad přední stěnou (obrázek 1). Několik minut po odpojení systému LUCAS progredovala bradykardie do srdeční zástavy. Bylo proto nutno pokračovat v krátké 10minutové manuální srdeční masáži, zvýšit dávku katecholaminů (noradrenalin $0,3 \mu \mathrm{g} / \mathrm{kg} / \mathrm{min}$ ), byl podán bikarbonát a byla zavedena kardiostimulační elektroda do pravé komory. Po oběhové

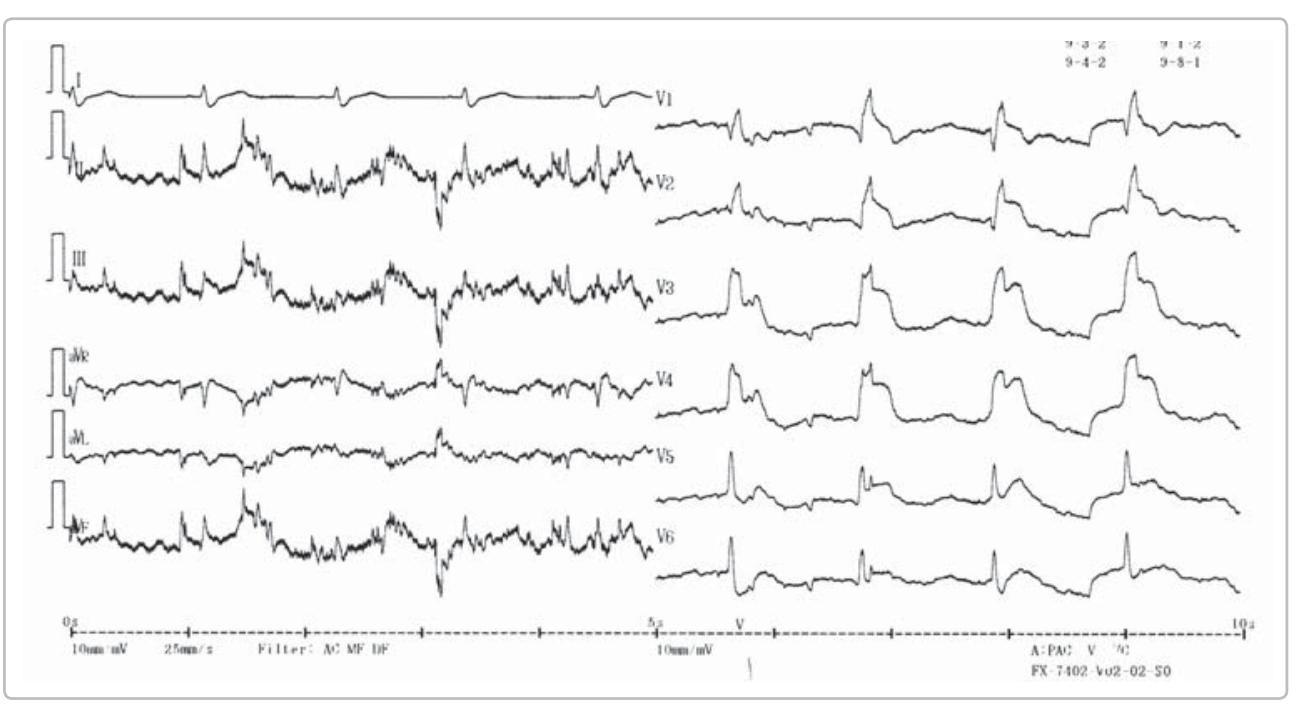

Obrázek 1 EKG při přijetí: blokáda pravého Tawarova raménka a elevace úseku ST nad přední stěnou 

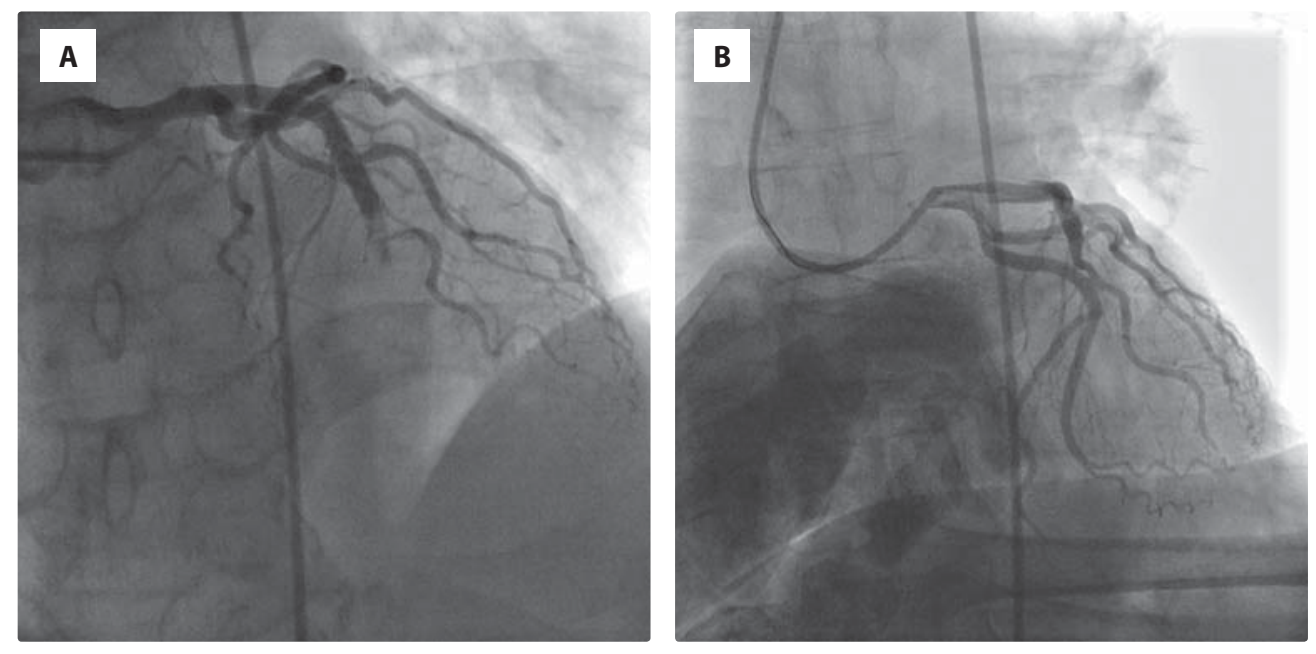

Obrázek 2 A) Selektivní koronarografie s nálezem uzávěru ramus interventricularis anterior (RIA) v celé jeho distální polovině; B) Zprůchodněná RIA po trombaspiraci stabilizaci byla provedena selektivní koronarografie s nálezem uzávěru ramus interventricularis anterior (RIA) v celé jeho distální polovině (obrázek 2a). Následnou trombaspirací několika bílých trombů se podařilo část uzavřeného úseku zprůchodnit (obrázek $2 b$ ), nicméně periferie $\mathrm{v}$ oblasti hrotu zůstala embolicky uzavřena. Významná stenóza tepny v místě uzávěru přítomna nebyla,

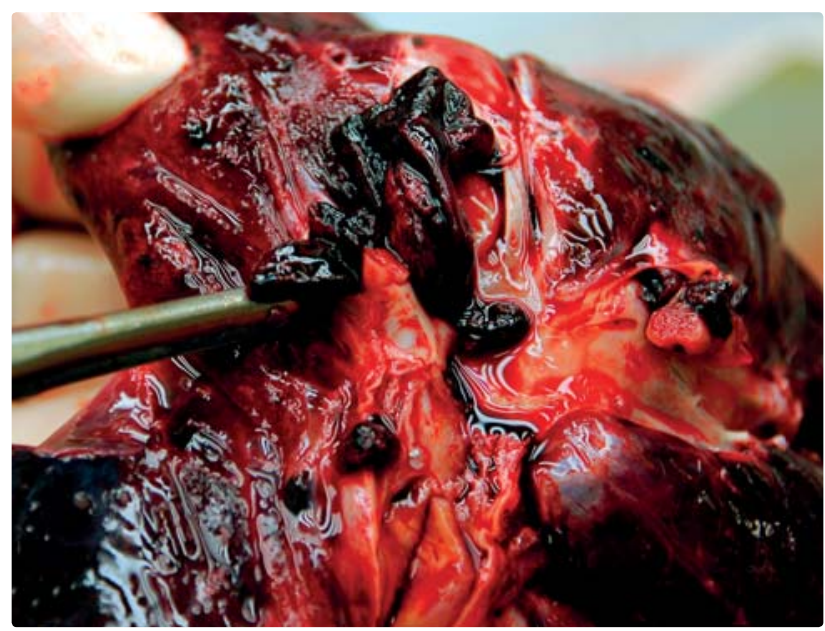

Obrázek 3 Makrosnímek z pitvy - akutní masivní trombotická embolie plicní tepny oboustranně

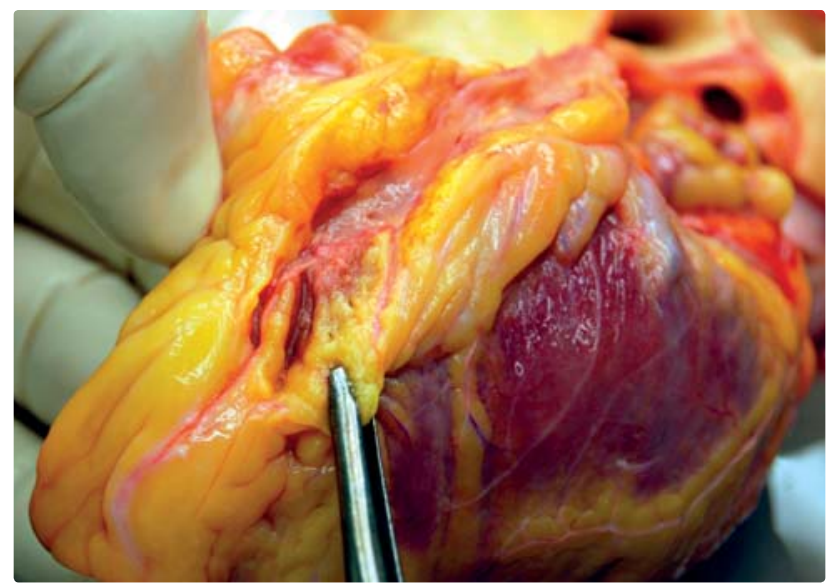

Obrázek 4 Makrosnímek z pitvy - volně průchodný RIA (po rozstřižení) a proto nebyl implantován stent. Po výkonu byl pacient při katecholaminové podpoře (noradrenalin $0,3 \mu \mathrm{g} / \mathrm{kg} / \mathrm{min}$ ) hemodynamicky stabilní, odvezen na koronární jednotku, kde po 40 minutách došlo opět k srdeční zástavě s elektromechanickou disociací, tentokrát s již neúspěšnou resuscitací. Pacient zemřel za 4 hodiny a 40 minut od primární zástavy.

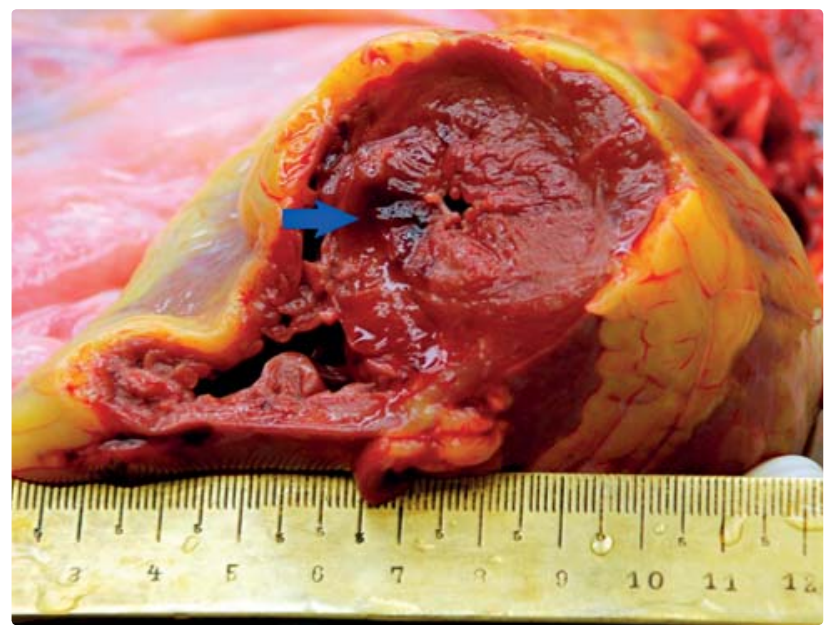

Obrázek 5 Makrosnímek z pitvy - ložisko pohmoždění (viz šipka) v mezikomorovém septu

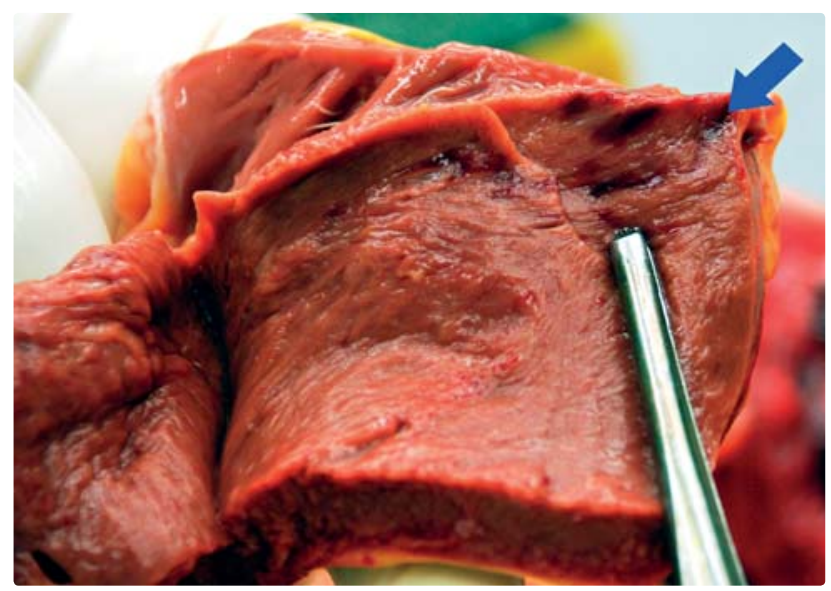

Obrázek 6 Makrosnímek z pitvy - ložiska pohmoždění (viz šipka a pinzeta) v přední stěně levé komory 


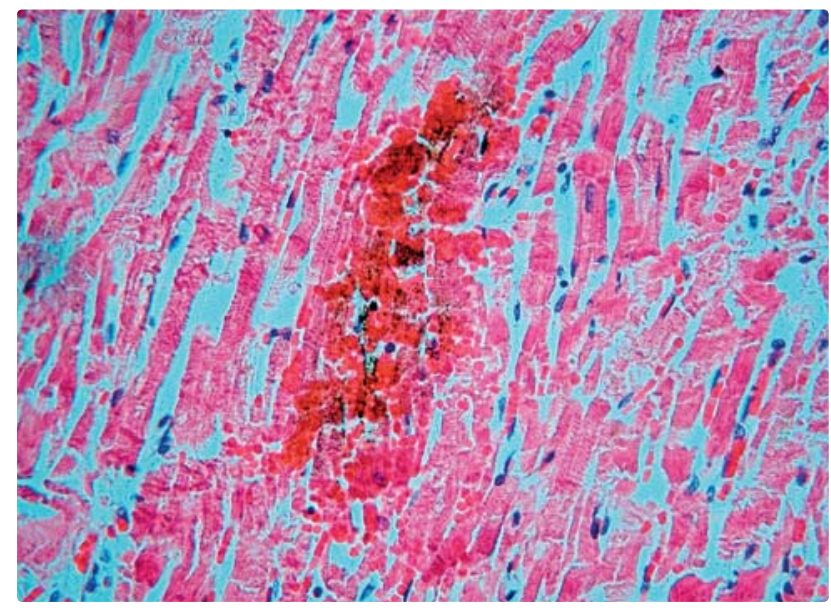

Obrázek 7 Histologický preparát - excize z přední stěny levé komory s ložisky hemoragie

Jako přičina smrti byla při pitvě zjištěna akutní masivní trombotická embolie plicní tepny oboustranně (obrázek 3). RIA byl volně průchodný, makroskopicky bez známek aterosklerotického postižení (obrázek 4). Pitvou bylo zjištěno: zlomeniny žeber oboustranně, zlomenina hrudní kosti, pohmoždění dolního laloku levé plíce, pohmoždění srdečního svalu v mezikomorovém septu (obrázek 5) a přední stěně levé komory srdeční (obrázek 6), krevní výrony v předním mediastinu a podél průdušnice. Histologickým vyšetřením byla v místě pohmoždění srdečního svalu prokázána ložiska hemoragie (obrázek 7), avšak nebyly prokázány změny svědčící pro akutní infarkt myokardu.

$\mathrm{Na}$ možnost sekundárního vzniku akutního STEMI přední stěny je třeba myslet u pacientů po protrahované resuscitaci, a pokud klinický obraz není typický, zvažovat u těchto pacientů i další možné prř́činy oběhové zástavy, např. plicní embolie.

\section{Literatura}

1. Wigginton JG, Miller AH, Benitez FL, Pepe PE. Mechanical devices for cardiopulmonary resuscitation. Curr Opin Crit Care 2005;11:219-223.

2. Smekal D, Johansson J, Huzevka T, Rubertsson S. No difference in autopsy detected injuries in cardiac arrest patients treated with manual chest compressions compared with mechanical compressions with the LUCAS device-A pilot study. Resuscitation 2009;80:1104-1107.

3. Buschmann CT, Tsokos M. Frequent and rare complications of resuscitation attempts. Intensive Care Med 2009;35:397-404.

Došlo do redakce 25. 6. 2010

Prijato 16. 4. 2011 